\title{
THE PROTECTION OF CONSUMERS' RIGHTS AND THE APPLICATION OF CRIMINAL LAW IN THE UNLAWFUL OPERATION OF SERVICES AND CONTENT SERVICE APPLICATIONS
}

\author{
Dr. Edmon Makarim, S.Kom., SH., LLM ${ }^{1}$
}

\begin{abstract}
Media reports on cases of the theft of pre-paid pulses taking place nowadays have created a misunderstanding in terms of the appropriate application of criminal law. In the context of existing legal provisions concerning consumer protection as set forth both under the Consumer Protection Law as well as in part under the Telecommunications Law, law enforcement agencies are leaning towards applying general criminal provisions (theft) which, after a careful observation of the Indonesian Criminal Code, in fact do not extend to corporate criminal acts. This paper purports to explain that the currently occurring cases of the theft of pre-paid pulses should be adequately dealt with by imposing administrative sanctions by the governing and supervisory agencies, both under the Telecommunications Law as well as the Consumer Protection Law. It is proposed that it would be more effective to apply the Consumer Protection Law in such cases, as it contains provisions concerning the threat of alternative criminal punishment in the form of confinement or fines, along with additional sanctions in the form of an order to pay compensation for damages to consumers accompanied by the seizure and the halting of the application system in use by the Operator and/or CP concerned. It is proposed that in administering a proper telecommunications system to the public, the application of the Consumer Protection Law is likely to be less counterproductive as opposed to the application of general criminal provisions, considering that the latter are contradictory to the principles of legal certainty and partnership mandated under the Telecommunications Law itself.
\end{abstract}

Key words: consumer protection, theft of pulses.

\section{Introduction}

News have been spreading in Indonesia recently concerning criminal acts of the theft of pulses, allegedly committed by business actors operating telecommunication networks and services (hereinafter referred to as Operators) in collaboration with telecommunication service business actors providing content (Content Providers, hereinafter briefly referred to as CP). This is in fact not an entirely new issue. Users of pre-paid telecommunication services have long felt that they have been losing pulses purchased through the mechanism of pre-paid vouchers.

${ }^{1}$ The author is Faculty Member for Telematics Law Research at the Faculty of Law of Universitas Indonesia (FHUI). 
Technically speaking, there may be several modus operandi for the theft of pulses; however, it generally occurs by charging unwanted telecommunication services to users. Basically, the user concerned may be either unaware of such deduction of pulses taking place, or may be mislead to enter into a commitment by being registered as a customer without actually giving consent. The ringback-tone on a customer's cell-phone is one of the examples that can serve to illustrate this point. Initially, some Operators tend to offer this feature free of charge as promotion, however, the user concerned is subsequently registered which is considered as an act of giving consent to the accept the use of such service feature which is to be extended in the subsequent month unless the user concerned states its withdrawal or rejects renewal. At the same time, it is generally felt among consumers that the feature for rejection, deactivation or deregistration (known under the popular term "unregister") does not function properly.

In addition to the above, the theft of pulses also occurs as a result of premium SMS services, whereby users subscribing for certain content are charged premium SMS charges for each SMS they send or receive. There is a great variety in the form of offers and promotion. There are content services offered through operators launching promotion through SMS broadcasting, while some others are promoted through other forms of media such as mass media advertising (TV broadcasting or newspapers), inviting potential customers to register as an act of consent to subscribe. Moreover, in the course of the latest developments, Operators are using pop-screen technology attached to the SIM card hardware at the time of issuing new numbers, whereby the system automatically activates a content service menu to customers. The question still remains whether such system automatically effects registration, or whether the consumer's confirmation is required as an act of consent to subscribe for a certain content.

In fact, the issue of stealing from customers is not a new one, it occurred several years ago, in response to which the Minister for Communication and Information issued Ministerial Regulation No.: 1/Per/M.Kominfo/01/2009 Tahun 2009 concerning the Operation of Premium Message Services and Short Text Messaging to Multiple Destinations (Broadcast), hereinafter referred to as "Premium SMS Ministerial Regulation". It basically provides for the provision of content services by Content Providers. ${ }^{2}$ However, reoccurrence has given

${ }^{2}$ The Premium SMS Ministerial Regulation contains substantive provisions regarding, among other things, requirements for the operation, imposition of BHP, the operational mechanism (subscription and non-subscription), compensation for damages, the transmission of SMS broadcast, sanctions, supervision and control by BRTI, as well as transitional provisions. This ministerial regulation is also complemented with two attachments, the first concerning the format of registration data required, namely: the name of premium message operator concerned, the person in charge (president director), the operator's address, the type of services being offered, the mechanism of operations (the alternative choice of either becoming or not becoming a subscribing customer by crossing out the unnecessary), cooperation partner (network operator), access number, call centre, the tariffs applicable, and the procedure for registration or deactivation. The Second Attachment is a statement by the Board of Directors stating that they will comply with their obligations as premium message service operators and will duly observe the applicable laws and regulations. This Ministerial Regulation is supported by BRTI Circular Letter No.: 133/BRTI/VIII/2010 concerning the Implementation of the said Premium SMS Ministerial Regulation dated August 11, 2010. This Circular Letter was issued in view of BRTI's findings in the course of supervision conducted by it, namely that in organizing premium message and short messaging service/SMS to multiple destinations (broadcast): (i) -There are (i) -Operators of premium messaging services that have not yet obtained a license, yet they have been providing premium messaging services; (ii) -The use of access number not 
rise to grave concern and criticism by the public as to the ineffectiveness of the said regulation. Speculation has become widespread concerning favoritism to Operators or the existence of conflict of interest between the government cq the Indonesian Telecommunications Regulatory Board (Badan Regulasi Telekomunikasi Indonesia or briefly referred to as "BRTI") ${ }^{3}$ and Operators. The situation has been further aggravated by the government's relatively slow movement in taking action for the prevention of increasingly protracted consumer losses, even though the government cq BRTI eventually imposed a moratorium by virtue of Circular Letter No. 177/BRTI/X/2011 for all such content services, except for those which had previously entered into a contract with the users of services concerned. ${ }^{4}$

It needs to be noted that the content industry was initially growing rather intensively, promising great alternative opportunities to business actors. This is rather logical in view of the impacts created by tight competition and the growing Blackberry services, leading to a decrease in the use of basic telephony and SMS services. Obviously, Operators had to look for other ways to make profits from the content industry. Specifically the RBT feature, which became registered with BRTI, yet used in the operation of premium messaging services; (iii) - Senders of Short Messaging Services/SMS to multiple destinations (broadcast) not providing the facility to the receivers of message to reject the subsequent message; (iv) - After the receiving party rejects the subsequent message, the sender of Short Messaging Service/SMS to multiple destinations (broadcast) persists in sending the next message. Therefore, by virtue of the said Premium SMS Ministerial regulation, which sets forth that premium SMS services can be operated after a license is obtained (Article 22 paragraph 1), whereas the license concerned is in the form of the registration of operating premium SMS services with BRTI (Article 22 paragraph 2); -Premium SMS services are operated by using a certain access number (Article 4 paragraph 1) and - Senders of Short Messaging Service/SMS to multiple destinations (broadcast) are obligated to provide the receivers of such messages with the facility to reject the subsequent message (Article 18), whereby after the receiving party rejects the subsequent message, the party sending Short Messaging Service/SMS to multiple destinations (broadcast) is prohibited from sending any subsequent messages (Article 19). Therefore, BRTI has instructed telecommunication operators to: (i) Halt premium message services and access numbers that have not yet obtained a license from and have not been registered with BRTI (attached are data on operators of premium messaging services and access number registered with BRTI as of May 26, 2010); (ii) Require parties sending Short Messaging Service/SMS to multiple destinations (broadcast) to provide the parties receiving messages with the facility to reject any subsequent messages and after the party receiving the message rejects any subsequent messages, the party sending Short Messaging Service/ SMS to multiple destinations (broadcast) has the obligation not to send any subsequent messages; and (iii) Duly observe all provisions of the SMS Ministerial Regulation without prejudice to the above described findings.

${ }^{3}$ Decree of the Minister of Transportation No. 31/2003 as amended with Regulations of the Minister of Communication and Information No. 25/Per/M.Kominfo/11/2005, No.33/Pe/M.kominfo/10/2008 and No.31/Pe/M.kominfo/8/2009 concerning the stipulation of BRTI revising the Decree of the Minister of Transportation No. KM.31 Year 2003 concerning the Stipulation of the Indonesian Telecommunications Regulatory Body (BRTI). In addition to the authority for multimedia licensing, BRTI also has regulatory, supervisory and control authorities. (10 Regulation includes the formulation and stipulation of provisions concerning the operation of telecommunication network and services, namely as follows: Licensing for the operation of telecommunication network and services; operational performance standards; interconnection fees; telecommunication tools and equipment standards. (2) Supervision of the operation of telecommunication network and services, namely: (i) operational performance; (ii) business competition; (iii) the use of telecommunication tools and equipment. (3) Control of the operation of telecommunication network and services, namely as follows: (i) dispute settlement between telecommunication network operators and telecommunication service operators; (ii) the use of telecommunication tools and equipment; (iii) the application of service quality standards.

${ }^{4}$ Instruction in Circular Letter SE 177/BRTI/X/2011 basically instructing as follows: (i) halt the provision of content through SMS broadcast; (ii) deactivate/unregister all types of services and enable re-registration for consenting parties, (iii) request recapitulation data on the user's pulses which have been deducted, (iv) require to return the pulses to the users concerned, and (v) require business actors to comply with the mandatory requirement to report in writing and periodically. 
an alternative to artists and the recording industry in reaping economic value from song compositions used as RBT, as the issue of record piracy had not been tackled properly. However, it appeared that the industry became disrupted as a result of the BRTI moratorium, giving rise to claims by CP business actors to $B R T I$, claiming that BRTI's arbitrary actions had caused CPs to suffer significant losses. At the same time, the Parliament also took note of the consumers' above described aspirations and concerns, it formed a working group to address the issue of the theft of pulses, and urged law enforcement agencies to impose criminal punishment on deceitful CPs in order to create a deterrent effect and ensure that actions would not be repeated. ${ }^{5}$ This issue became the center of an increasingly heated debate in light of the opinion expressed by criminal law experts stating that the provisions of the Anti-Money Laundering Law would have to be applied in these cases in order to ensure that all parties involved were subject to thorough investigations. It was alleged that the revenues obtained from the theft of pulses were rather significant reaching trillions of rupiah, presumably involving a great number of parties in the distribution of such revenues, thus calling for a complete investigation down to the very roots. ${ }^{6}$

This protracted polemics surrounding the issue of the theft of pulses is a very interesting topic for research, not only because it raises public concern with a view to the issue of stealing from the small people, but because they also seem to indicate that the provisions of existing laws and regulations appear to be inappropriate or ineffective. Due to the existing ambiguities concerning the responsibility of business actors to consumers as well as the ambiguities in state administrative rules in the context of content services, this issue does not end with the recovery of consumers' rights for the losses suffered; rather, it calls for the application of general criminal provisions in order to fulfill the sense of justice to the people who have served as an arena for exploitation by business actors. The imposition of penalties is considered to be no longer adequate for the purpose of creating a deterrent effect for perpetrators. It has become what appears to be a commonly accepted assumption that almost all Operators are suspected of committing a very similar form of deceit. Cases in which the National Police (POLRI) have determined several persons as suspects in companies allegedly committing such deceit (CP, Operators) are currently being handled or investigated.

Based on the foregoing, the author is of the view that there is a need for a more comprehensive research and analysis of this issue, by observing all types of legal liabilities under prevailing laws and regulations, including civil, administrative as well as criminal liabilities.

\section{Analysis of the Telecommunications Law and Consumer Protection Law}

The first interesting point to be analyzed is the proposition that legal provisions in the area of telecommunications are not yet effective in keeping up

${ }^{5}$ The author was one among the experts who were requested to provide an opinion in the Public Hearing Meeting, and felt there was something rather unusual in these discussions as they appeared to be focused on ideas directed at CPs frequently accused of being deceitful CPs, while there was almost no mention at all of the fault of Operators.

${ }^{6}$ Detik.com, (2012). Police: Losses from Toll Theft More Than Rp 1 Trilion, accessed at http://inet. detik.com/read/2012/03/22/190313/1874860/328/polisi-kerugian-pencurian-pulsa-lebih-dari-rp-1triliun 
with the dynamics of convergence of telecommunications, media and informatics ("convergence of telematics"). One of the manifestations of such dynamics is the provision of content service features (Content Service Providers) in the business of operating telecommunication network and services. In popular terms, such dynamics is referred to as the development of a new industry, namely the Content Providers ("CP"). Previously The government's imposition of Fee for Operational Rights/Biaya Hak Penyelenggaraan (" $B H P^{\prime}$ ) on content providers triggered debate and strong opposition by the Association of Content Providers, who eventually filed for judicial review with the Supreme Court at that time.

It needs to be noted that the Indonesian Telecommunications Law, just as the Telecommunications Law in other countries, does not contain many ex-ante Consumer and Business Competition provisions, considering that the paradigm of telecommunication operations is aimed fulfilling consumers' objective. ${ }^{7}$ Accordingly, the Ministry of Communication and Information (hereinafter referred to as Kominfo) has the authority to issue regulations for consumer protection as a preventive measure. Furthermore, the policy pattern set out in the Regulation of the Minister of Kominfo No. 1 Year 2009 concerning the Operation of Premium Message Services and Short Text Messaging (SMS) to Multiple Destinations (broadcast) is also rather unique, because in its capacity as the state administrative agency which has the authority to control, manage and administer the operation of telecommunication services, it appears that Kominfo is providing a different legal treatment. While it is stated in the Telecommunications Law that in principle every operation of telecommunication network and services must go through a prior licensing process, in the context of the telecommunication content industry it is sufficient for content providers to file for registration. ${ }^{8}$ There may be a well-intentioned purpose behind such policy, namely to encourage the development of the content industry, whereby the government deems it necessary to eliminate its intervention. However, this becomes a boomerang to the government, or to use the Indonesian saying, it is like eating the simalakama fruit $^{9}$.

Indeed, at a glance, the provisions of the said Premium SMS Ministerial Regulation appear to be adequate, as they set forth a mechanism for administering subscriptions (without prior registration), the provision of call centers, the minimum standard for the administration of the prohibition to impose registration fee, and similar matters. However, the administrative impact of merely requiring registration is the tendency to engage in free business and it creates an opportunity for misappropriation or non-compliance with the substantive rules set out in the above mentioned ministerial regulation. Operators of such services do not have to go through the prior operational eligibility test, which leads to the logical conclusion that there is no adequate

${ }^{7}$ John Buckley. (2003). Telecommunications Regulation, London: The Institution Of Electrical

${ }^{8}$ Article 2 of the Regulation of the Minister of Communication and Information No.1 Year 2009, paragraph (1): premium messaging services are provided after a license is obtained, paragraph (2): the license as intended in paragraph (1) is in the form of registration at BRTI for operating premium messaging services. (30 Registration as intended in paragraph (2) is conducted by using a registration form and attaching a statement as intended in Attachments I and II of the regulation.

${ }^{9}$ The Indonesian saying is as follows: "bagai makan buah simalakama: dimakan bapak mati, tidak dimakan ibu mati", which literally translates as "it is like eating the Simalakama fruit; if you eat it, your father will die; if you don't eat it, your mother will die'. It is used to describe a deadlock condition, in which decision must be made, but there is not a really good choice, whichever way one decides, it is bound to cause regret. 
supervision of the application system used. It appears as though Operators and CPs are installing and setting their systems as they wish, following their own agreement, without being subject to prior examination.

Parallel to that, Operators and CPs also appear to be creating an incorrect public perception of the business concept pattern, often treating it as an analogy of a separate business between suppliers of communication mere conduit and the content providers as a destination calls. In their understandings, the Operators are providing only the mere conduit as the communication channel, while the content service is actually a direct legal relationship between the user and the CP. They thought this is similar business model to conventional mass media publications, where the Operator is only implementing the printing function, while the printing press does not take responsibility for the contents. The Operator takes the position that if something goes wrong with the providing services of content it is beyond the Operator's responsibility, those being entirely the CP's responsibility and liability, as the CP's presence is already known and recognized as a separate industry.

However, there is an interesting fact because actually before the User accept the services from the CP or Operator, there has already had a prior cooperation agreement between the $\mathrm{CP}$ and Operator for delivering their services to the users. In the context of some certain cases, the business model was originally came from Operator's initiative therefore it could be started even before the Cooperation Agreement is signed by the CP, the parties deemed sign such Cooperation Agreement subsequently. This raises the question as to whether these are actually separate businesses, or perhaps the content services industry is actually in fact a derivative business of certain parties which might be have a close relationship with the Operator. If that is the case, the Operator is clearly in a position to determine anybody as its CP. Thus, the Operator has an extremely dominant bargaining position, and therefore naturally the $\mathrm{CP}$ just follows the operating business model determined by the Operator. All of the incomes actually came from the Operator's side in delivering their network services.

From the business point of view, how to proceeds from the access to the providing the content constitute the Operator's and CP's shared revenues. Moreover, the CP's share in such revenues is in fact determined based on the periodic reports on the calculation of the use of services, which are collected by the Operator, and are first deducted by the Operator's share in advance. In practice, CPs fully rely and comply with the Operator's reports and their merely policies, as they have no direct access to the system recording use and billing system operated by the Operators.

Technically speaking, the Application System used is not developed by the $\mathrm{CP}$, rather, it is obtained from the Operator, it was installed and connected to the Operator's computerized system. In other words, the installation and validity of the system is obviously highly dependent on the operator's server. The CP is unable to access data on customers and the users of the Operator's services directly, it has to obtain authorization from the Operator's server. The aforementioned facts on technical and business patterns raise an issue related to fair business competition. Considering the dominant position of Operators vis-a-vis CPs, Kominfo should exercise its authority to ensure that for the purpose of opening up a business opportunity to the content industry there is 
no conflict of interest between Operators and CPs cooperating with them. The regulation pattern under the Telecommunications Law has opened the way for ex-ante regulation to ensure the soundness of this industry. ${ }^{10}$ Accordingly, giving up supervision and control over the business model of their cooperation is an inappropriate policy.

At the same time, it certainly raises a big question from the consumers' perspective, namely whether from the point of view of consumers their responsibilities can be separated, while as far as consumers are concerned they should be liable jointly and severally. In the consumers' perspective, the scope of business actors dealing with consumers certainly includes every business actor jointly and directly contributing to the operation of services used by the consumers concerned. Even more uniquely, the basic contract is the use of network with the consequence of paying for the pulses used; accordingly, in the mind of consumers the basic legal relationship is in fact the use of the telecommunication network and services concerned. In the context of using content services, the pulses used are a tool of payment. Content supply is an additional feature with the consequence of the used pulses being charged by the Operator, rather than being billed separately by the CP directly to customers. This can be in the form of billing for content subscription services to users of telecommunication services by the Operator, or deducting pulses in a value equivalent to the amount of the service fee by the operator as revenue sharing between the Operator and CP concerned.

It is also interesting to observe the provision of Article 1 sub-article 11 of the Telecommunications Law which sets forth that users of telecommunication services are Customers and Users. Based on sub-articles 9 and 10, distinction is made between the definition of Customer and User. ${ }^{11}$ In practice, the general understanding is that Customers are post-payment users bound by a subscription contract, while Users are consumers who are not bound by a contract.

In practice, such discrepancy in perception also brings an impact of technical nature on the quality of customer services, namely, users do not receive periodic reports on use as customers do, they only have the facility to check the total amount of remaining pulses, without specific information concerning the log data on use. There appears to be a contradiction between the operation of telecommunication services in practice and the provisions of Article 14, 17, 18 and 19 of the Telecommunications Law itself, which do not articulate such distinction clearly. ${ }^{12}$

${ }^{10}$ Article 10 paragraph (1) of the Telecommunications Law provides for the prohibition of telecommunication operation activities which may potentially cause monopolistic practices and unfair business competition among telecommunication operators. At the same time, paragraph (2) provides that the Prohibition as intended in paragraph (1) is in accordance with the applicable laws and regulations. Even though these provisions refer back to Law No. 5 Year 1999 concerning the Prohibition of Monopolistic Practices and Unfair Business competition which is an ex-post regulation, the consequence of its being mentioned in the Telecommunications Law is that it becomes an ex-ante provision and it is the duty of the administrative authority concerned to exercise supervision.

${ }^{11}$ Customers are individuals, legal entities, government agencies using telecommunication network and/or services based on contract; at the same time, Users are individuals, legal entities, government agencies using telecommunication network and/or services without a contract; (underline by the author).

12 Article 14: Every user of telecommunications has an equal right to use telecommunication network and services with due observance of applicable laws and regulations. Article 17: Operators or telecommunication network and/or services are obligated to provide services based on the following principles: (a) equal treatment and the best possible services to all users; (b) enhanced efficiency in the operation of telecommunications; and (c) the fulfillment of service standards and the provision of facilities 
The big question is, whether it can be considered that Operators and CPs fulfill their obligations as business actors to protect consumers' rights as set forth, among other things, in Article 14 of the Consumer Law, namely: (i) the right to have comfort, security and safety in consuming goods and/or services; (ii) the right to choose goods and/or services as well as to obtain such goods and/or services at the exchange value, in the condition and with the assurances as promised; and (iii) the right to correct, clear and honest information about the condition of and assurances related to the goods and/or services concerned.

Basically, consumers' right to have security and safety is in fact also a manifestation of the protection of the principle of every person's Privacy. In general, the protection of privacy is not limited to protecting one's comfort by not being disturbed (no intrusion from another party); rather, it extends to the confidentiality of information and/or communication, as well as to the disclosure, the use or processing of an individual's personal data, in this case the appropriate processing of consumers' data by the Business Actors concerned. Broadly speaking, there are two essentially different approaches to privacy. The first variant is the US model approach, which considers the subjective values of the person concerned, whereby privacy is dependent on the legal subject's 'reasonable expectation to privacy'. The derivative of this model is the 'Option Out' principle, namely any person's right to communicate with another person, unless such other person rejects it. On the other hand, the second variant is the European Union model approach, which considers the appropriateness of material value in obtaining another person's private information; in this context it is understood that private data is the property of the legal subject concerned, hence it is the obligation of every person to protect another person's data and to ensure that it is obtained legally. The derivative of this model is the 'OptionIn' principle, according to which every person must protect another person's personal data and must ensure that it is obtained and processed in compliance with the law, in a manner that does not conflict with the security and comfort of the proprietor of the data concerned.

Based on the foregoing it becomes obvious that privacy in communication does not only imply security and comfort in using or utilizing telecommunication network products and services; rather, it also includes the comfort of privacy and the protection of personal data provided by consumers to business actors, which is in fact provided with consent for the process of transaction with the Operator only, and not any other party. Essentially, the Operator never receives consent to disclose such data to another party. Therefore, the proposal put forward by business actors to amend the SMS Premium Ministerial Regulation based on the 'Do Not Call Registry' paradigm is in fact a mistake.

It can be stated that the Indonesian legal system does not adopt the 'option-out policy' as the Telecommunications Law does not accommodate it, while the Consumer Law expressly provides for the Consumers' rights and comfort. In addition to the above, there are also provisions with regards to

and infrastructure. Article 18: (1) Operators of telecommunication services are obligated to note/record in a detailed manner the use of telecommunication services by users of telecommunication services. (2) In the event that the users require notes/records of telecommunication services as intended in paragraph (1), the telecommunication operator concerned shall be obligated to provide the same. (3) Provisions concerning the noting/recording of telecommunication services as intended in paragraph (1) shall be provided for in a Government Regulation. Article 19: Telecommunication network operators are obligated to ensure the users' right of freedom to choose another telecommunication network to meet their need for telecommunication. 
personal data under Article 26 of law No. 11 Year 2008 concerning Information and Electronic Transactions (hereinafter briefly referred to as 'UU-ITE') ${ }^{13}$ requiring approval from the proprietor of the personal data concerned. In fact, every business actor should be aware of their obligation to protect consumers' rights, and that violations of such obligation may lead to the threat of criminal sanctions. Based on such premise, it is not the consumers' obligation to register their wish not to be disturbed by promotional information from the business actors concerned; on the contrary, it is in fact the business actors' obligation to create a 'white list' based on consumers' consent to receive such information. ${ }^{14}$ It is not surprising that the YLKI (Indonesian Consumers Foundation) and the Consumer Protection Agency (BPKN) have strongly objected to this, urging the government to implement better regulation.

In the consumers' perspective, Law No.8 Year 1999 concerning Consumer Protection should be duly observed by Business Actors in providing goods or services, including the prohibitions which bring the consequence of criminal sanctions for business actors, among other things the provisions of Article 8 subarticle (f), Article ${ }^{15}$ and Article $15^{16}$ jo. Article $62^{17}$ of the Law of the Republic of Indonesia Number 8 Year 1999 concerning Consumer Protection. At the least, an agreement which appears to be a forced agreement because it is entered into

${ }^{13}$ Article 26 of UU-ITE: (1) Unless provided otherwise in a Government Regulation, the use of any information through the electronic media related to the personal data of an individual must be based on the approval of the Person concerned. (2) Any Person whose right as intended in paragraph (1) is violated can file a claim for the damages suffered based on this Law. In the elucidation on this article, it is further stated as follows: in using information technology, the protection of personal data is part of privacy rights. Privacy right is defined as follows: (a) Privacy right is the right to enjoy one's personal life free from all kinds of disruptions. (b) Privacy right is the right to communication with other People without being spied upon; (c) Privacy right is the right to supervise access to information concerning the personal life and data of an individual.

${ }^{14}$ Specifically with a view to operators, they also provide a black list of numbers which, based on reports/consumer complaints or based on their own findings are found to have been misappropriated for the purpose of committing unlawful acts (e.g.: spamming). In fact, operators must take responsibility for numbers by validating initial registration for the activation of numbers sold to users.

${ }^{15}$ Article 13 of the Consumer Law: paragraph (1) Business actors shall be prohibited from offering, promoting or advertising goods and/or services by promising complimentary prizes in the form of other goods and/or services while not intending to deliver the same or not in a manner as promised; paragraph (2): Business actors are shall be prohibited from offering, promoting or advertising medicine, traditional medicine, food supplements, medical equipment, and health care services by promising a prize in the form of other goods and/or services.

${ }^{16}$ Article 15 of the Consumer Law: Business actors shall be prohibited from offering goods and/or services by force, or in any other way which may cause physical or psychological disruption to consumers.

17 Article 61: Criminal prosecution may be conducted against business actors and/or their management. Article 62 paragraph (1) Business actors violating the provisions as intended in Article 8, Article 9, Article 10, Article 13 paragraph (2), Article 15, Article 17 paragraph (1) sub-paragraphs a, b, c and e, paragraph (2), and Article 18 shall be subject to the criminal punishment of not longer than 5 (five) years of imprisonment or the criminal punishment of fine of not more than Rp2,000.000.000.00 (Rupiah two billion); paragraph (2) Business actors violating the provisions as intended in Article 11, Article 12, Article 13 paragraph (1), Article 14, Article 16 and Article 17 paragraph (1) sub-paragraphs d and f shall be subject to the criminal punishment of no longer than 2 (two) years of imprisonment or the criminal punishment of fine of not more than Rp.500,000,000.00 (Rupiah five hundred million); paragraph (3) Violations which cause heavy injury, serious disease, permanent disability or death shall be subject to the prevailing criminal provisions. Article 63: In addition to the criminal sanctions as intended in Article 62, additional punishment can be imposed in the form of the following: (a) forfeiture of certain objects; (b) the announcement of the judge's decision; (c) payment of compensation for damages; (d) the order to halt certain activities which cause losses to consumers; (e) requiring to withdraw objects from circulation; or (f) revocation of the business license. 
based on negligence can be perceived as an act that psychologically disrupts consumers and it can eventually lead to the imposition of criminal punishment. However, it needs to be understood that the threat of criminal punishment under Article 62 of the Consumer Law is an alternative punishment, a combination of criminal punishment of detainment and fine. This follows from the principles of balance and legal certainty adopted in the Consumer Protection Law.

The protection of consumers' rights is basically certainty in the recovery of consumers' rights and improved quality of services on the one hand, and protection in the context of certainty for conducting business activities on the other. Therefore, within the scope of corporate action criminal punishment in the form of fine, rather than detainment, should be given priority, unless there is misappropriation for personal interest by members of the board of directors acting beyond their authorities. Indeed, the deterrent effect towards corporations should not be aimed at extinguishing the corporation itself. That would be counter-productive in providing public services in the area of telecommunication. Moreover, in this context the government is not the investing party; it is the business actors who are making investments and therefore they should also be able to obtain legal certainty related to their investment.

In connection with the above, there is a need to observe the provisions of Article 63 of the Consumer Law, stating that in addition to criminal sanctions as intended in Article 62, additional punishment can be imposed in the form of the following:
a. forfeiture of certain goods;
b. announcement of the judge's decision;
c. payment of compensation for damages;
d. order to halt certain activities which have caused losses to consumers;
e. requiring the withdrawal of goods from circulation; or
f. revocation of business license.

Based on the above mentioned Article, law enforcement agencies are vested with the authority to seek interlocutory decision for the seizure and forfeiture as well as the halting of the application system used by the Operator and/or CP concerned, in order to prevent continued losses from occurring. The above mentioned Article also purports to ensure justice, whereby in addition to being imposed with the criminal punishment of fine, the business actor found guilty of committing violation can be ordered to pay compensation to consumer for the damages incurred. In the author's opinion, with the provisions of this article there is no longer a need to apply general criminal punishment articles, unless the fault of individuals abusing their office is found in the course of investigation, in which case general criminal punishment articles would be applicable against the individuals concerned.

\section{Analysis of the Administrative Liability of the Kominfo Ministry and BRTI}

As we know, the state administration has the authority to foster and supervise the operation of telecommunication. Based on the foregoing, it would appear that Kominfo has not been entirely successful in formulating appropriate rules, which is quite usual in view of the intensive dynamics taking place in the 
convergence of telematics that appear to bring fundamental changes to wellestablished paradigms. In the perspective of state administration, the essential question is whether the authority of State Administration may diverge from (if not contradict) the responsibility to regulate the licensing mechanism based on law? Is the Regulatory Body in a position to implement administrative functions while its authority is limited to formulating regulations? The supervisory and control function should not be implemented administratively by the BRTI, which is clearly in the regulatory domain. Certainly not with the argument that its chairperson and secretariat are supported by the Directorate General of Post and Telecommunications, wherefore the administrative function of licensing and control can be implemented by BRTI. Such authority should be returned to the Ministry, while the BRTI should revert to its regulatory and supervisory function.

As a consequence of the registration mechanism, content can be provided without re-inspecting the application system in use. The implication of this is that under Kominfo's policy there seems to be a separation between the application system and the integral nature of the information and communication system managed by the Operator. This indicates the there is an inconsistency, as such system is certainly bound to have a direct impact on the existing systems which were subject to prior operational eligibility test by Kominfo, as well as on the quality of the service concerned.

As a result of public pressure, Kominfo cq. BRTI eventually took a firm step towards implementing its authorities by stipulating the moratorium in the above mentioned Circular Letter, even though in certain aspects it still exceeds its authorities. The question still remains as to whether Kominfo actually reviews the applications, or it continues to reissue blank checks of trust to business actors. Applications should be seized and examined forensically to establish whether the system concerned has been developed and operated appropriately, or whether it actually involves a lie to the public as a result of potentially inappropriate differentiations in the conditioning of the system.

In the context of the application of the electronic system used, Kominfo should also implement the provisions of Article 15 of UU-ITE ${ }^{18}$ which essentially sets forth the requirement for business actors to organize their electronic systems in a reliable, secure and responsible manner. As a lesson learnt from the foregoing, the Ministry of Komfindo should realign itself in organizing its working functions, ensuring that immediate changes are made in the distribution of work, which tends to be parallel due to sectoral domination, to become serial distribution of work between the Directorate General of Operations (formerly the Directorate General of Post and Telecommunications) and the Directorate General of Informatics Application ("Ditjen Aptika"). Results of the examination conducted by Ditjen Aptika should become the decisive parameter in the operational feasibility test or in the action or control measures eventually undertaken by the Directorate General of Operations.

For the prevention of similar misappropriation in the future, Kominfo cq. Directorate General of Operations and Ditjen Aptika should take prompt measures

${ }^{18}$ In the elucidation on Article 15 paragraphs (1) and (2) it is stated that "Reliable" means that the Electronic System has the capacity which matches the need for its use. "Secure" means that the Electronic System is protected both physically as well as non-physically. "Operating properly" means that the Electronic System has the capacity in accordance with the given specification. "Responsible" means that there is a legal subject which is legally responsible for the Operation of the Electronic System concerned. 
to secure instruments of evidence, namely by seizing the application system used to provide content, by conducting prompt forensic analysis and by taking the necessary steps to ensure that individuals committing misappropriation are brought to justice. However, from the corporation's perspective, it can be accomplished by imposing criminal punishment in the form of fine.

Is is noteworthy that in addition to the administrative authorities of the Ministry of Kominfo, under the provisions of Article 60 juncto Article 52 subarticle (m) the Consumer Dispute Settlement Board ("BPSK") also has the authority to impose administrative sanctions. Unfortunately, the maximum amount of such administrative fines is limited, which to a certain extent creates the sense of injustice for consumers. The application of administrative sanctions by BPSK does not nullify the validity of administration sanctions imposed by Komfindo, so that they can be considered as complementary sanctions.

\section{Analysis of the Civil Liability of Operators and CPs}

It needs to be observed that, in principle, the contract between ConsumerOperator-Content Provider begins with the contract between the Consumer and the Operator to use their numbers for the purpose of accessingtelecommunication services, unless there is an initial agreement directly between the consumer and CP (e.g. the consent to receive information from the business actor at which they previously used to be customers), whereby all contractual commitments created through the operator are in fact derivative agreements. Accordingly, the primary responsibility should remain with the Operator.

Bearing in mind that the main contributor is the Operator which has the responsibility to ensure the security and comfort of its consumers, it is actually the Operator's duty to ensure that no misappropriation occurs in the access to the user's number. Basically, users of Telecommunication services only know and deal with the Telecommunication Operator in facilitating their need to communicate with third parties. In other words, the option of the right to call or to be called lies entirely with the user itself. Ergo, the existence of consumers and access to their personal data is an 'option-in' and it does not depend on the preparedness of the Operator which cooperates with the CP as its partner in providing services. Any disclosure without the approval of the proprietor of the personal data concerned is an unlawful act.

In the context of the validity of contract which is based on the mechanism of giving consent in electronic form, the question is whether the act of registering can be considered as giving consent. Based on Article 1320 of the Civil Code, registration cannot be interpreted as giving consent. Consensus is not created based on error, under pressure or duress, or deceit. Therefore, this mechanism, too, needs to be improved by introducing a mechanism enabling the consumer concerned to confirm after he/she receives complete and correct information concerning the proposal. The consequence of forcing an agreement as a result of ambiguous information or due to the non-functioning of a previously stated system is that the contract concerned becomes null and void by law because it does not meet the express requirement "concerning a particular matter" in the agreement. This becomes evident if there is no mechanism in place for ensuring the proper function of the deactivation facility.

Therefore, according to the concept of fault in an Unlawful Act (tort), which is not measured only based on norms in laws and regulations but also 
based appropriateness in developing business practices, business actors are liable for losses suffered by consumers. The norm against which fault is measured is set forth not only Article 15 of the Telecommunications Law, ${ }^{19}$ the Consumer Protection Law and in Article 15 of UU ITE, fault is also measured from the aspect of appropriateness, namely that business actors must act honestly in running their business. All of the above mentioned three laws adopt the paradigm of "presumed liability" by imposing obligation on business actors to pay compensation for damages to consumers. In other words, the basic assumption is that business actors must take responsibility, except for cases in which the fault is not caused by them. However, the question still remains: who has the burden of proving such fault? It would not be appropriate to put the burden of proof on consumers in this case, because they are not in a position to prove such fault as they do not have adequate access to the electronic system itself. Accordingly, by law and justice, the burden of proof returns to the business actors concerned. The business actors concerned, rather than consumers, are actually able to provide an honest explanation on the fault of the system.

Furthermore, based on the concept of interactive justice, which sets the liability for any person creating a risk to take anticipatory responsibility towards other parties, the principle of strict liability should be applicable. Consequently, the possibility of applying compensation for both material as well as immaterial damages can function as punitive damages or "penalty" for the purpose of creating deterrent effect to business actors exploiting consumers' indifference. The parties contributing to the operations must be jointly and severally liable for recovering consumers' rights.

\section{Analysis of General Criminal Liability}

It needs to be understood that the currently applicable Criminal Code refers to criminal acts committed by individuals, and there is still an ongoing debate as to whether it is applicable to criminal acts of corporations. There are at least three allegations of general criminal acts in the case of pulse theft. These include the application of the article on Theft (article 362 of the Criminal Code), ${ }^{20}$ Embezzlement (Articles 372, 373 or 374 of the Criminal Code) ${ }^{21}$ or

${ }^{19}$ Article 15 of the Telecommunications Law: (1) In the event of fault and/or negligence of a telecommunication operator which causes a loss, the parties suffering such a loss shall be entitled to file a claim for compensation for damages against the telecommunication operator concerned. (2) Telecommunication operators shall be obligated to pay compensation for damages as intended in paragraph (1), unless they can prove that such losses were not caused by their fault and/or negligence. (3) Provisions concerning the procedure for the filing and settlement of a claim for compensation for damages as intended in paragraphs (1) and (2) shall be provided for in a Government Regulation.

${ }^{20}$ Theft (Article 362 of the Criminal Code): A person taking an object, which is entirely or partially owned by another person, with the intention to use such object in an unlawful manner shall be subject to punishment for theft, with the punishment of imprisonment for no longer than five years or the fine of not more than Rp.900.

${ }^{21}$ Article 372: Any person who intentionally and in an unlawful manner possesses an object which is entirely or partially owned by another person, but which is not in such person's possession as a result of felony shall be subject to the threat of punishment for embezzlement, with the criminal punishment of imprisonment for no longer than four years or the criminal punishment of fine of not more than nine hundred rupiah. Article 373: Acts as defined under Article 372, provided that the embezzled objects are not in the form of cattle and the value does not exceed twenty-five rupiah, shall be punishable as the misdemeanor of embezzlement with the criminal punishment of no longer than three months of imprisonment or the criminal punishment of fine of not more than two hundred and fifty rupiah. Article 374: Embezzlement committed by a person whose possession of an object is caused by an employment relationship or due 
Fraud (Article 378 of the Criminal Code). ${ }^{22}$

In the author's view, it is difficult to apply the article on theft in this context, as it does not fulfill the essential elements of the crime as formulated in the Criminal Code. One of the key elements is the movement of an object/goods (barang) and the scope of definition of goods as an 'object' (barang). Indeed, in some electricity theft cases in the past the broad or widening interpretation of the 'object' was used at that time, thus the electricity could be intepreted as included in the scope of the definition of 'object'. Technically speaking, this was acceptable considering that there was indeed a movement taking place of the electricity which were moved through the cable electronically, namely the electronic flow itself. It could be proved by having the electricity power as the result. However, the question is whether it is possible to make a similar interpretation in this context, bearing in mind that in fact 'pulse'23 is not the same as an 'object' as well as the electricity. That is because, in technical meaning, pulse is namely a time unit of the use/utilization of telecommunication services. The transaction of purchasing prepaid pulses is not a purchase of an object; rather, it is a payment for the use of services in advanced, which is not based on the transfer of the ownership or possession of an object, but only a form of prepaid lump-sum fee for using the telecommunication network services which are yet to be used. An important point that requires attention in this context is the existence of a receivables right (piutang) for telecommunication services which have not been used yet.

At the same time, the articles on Embezzlement and Fraud may still be potentially applied, as all of the essential elements of their criminalizatio provisions may be fulfilled. Under the article on Embezzlement, it could be interpreted that the object should had indeed already in the possession of the perpetrator, as well as the pulse is in the electronic system managed by it, whereby the pulse and application are in the server's operator and/or CP operated with the perpetrator's authority. Similar is the case in the context of the application of the article on Fraud. The key element of the criminal provision is the existence of a series of lies for the purpose of providing or eliminating a debt/receivable can also be fulfilled if the application system used is not set appropriately. The results of a forensic examination of the CP's Application would be able to provide a more specific explanation on this matter. It may become evident from ambiguities and incorrect information conveyed to consumers by examining the setting of the application system on the perpetrator's server. The result of such endeavors is a reduction in the consumer's credit (receivables) in the form of the use of pulses. Unfortunately, whether the general criminal code (penal code) could be applied to the corporate crime or not, were still ongoing debate of some legal scholars. It was undisputed that those provisions could only be applied to the personal or the individual of the Board of Directors who might be abused his or her powers in their corporation.

to a quest or because the person concerned receives a fee for it, shall be subject to the threat of criminal punishment of imprisonment for no longer than five years.

${ }^{22}$ Fraud: (Article 378 of the Criminal Code): Any person acting with the intention to obtain personal benefit or benefit for another person in an unlawful manner either by using a false name or a false condition both with deceit and deception as well as lies in order to persuade a person to give an object, to enter into debt, or write off a receivable, shall be punishable for fraud subject to the maximum imprisonment of 4 years.

${ }^{23}$ In Indonesia, the unit of the electronic pulse usaged of the telecommunication netwok services is popularized as "Pulsa" 


\section{Conclusion} made:

Based on the foregoing explanation, the following conclusions can be

1. Based on its authorities, the Ministry of Kominfo should be able to act more firmly, as it has the pre-emptive authority to decide whether or not a certain content service can be provided to the public. The government has the capacity to do these both technically as well as administratively. With its supervisory and control authorities, as a central administration of ICT convergence, the government can also halt certain services if their implementation is harmful to the public interest. Services provided by Operators and CPs can be suspended, and the most thorough audit should be conducted on the electronic system application used. Therefore, Kominfo needs to improve its regulations, not only by revising the SMS Premium Ministerial Regulation based on the industry interest, but also to formulate more comprehensive rules in order to ensure that consumers' privacy, security and comfort are not disrupted. In the author's view, a ministerial regulation within the scope of the functions and duties of Ditjen Aptika cq. information security director is more relevant in this matter, as opposed to taking into account only the business model of operations from the telecommunications point of view. There needs to be a way to measure the achievement of expeditious enforcement aimed at preventing consumer losses, which can only be evident from the SOP for the implementation of control. The BRTI would appear to be negligent or unable to implement its control function if it detects a problem early on, but takes enforcement measures only a year later as a result of public pressure and advocacy.

2. The opportunity for misappropriation and inappropriate use of business opportunities by Operators and CPs arises as a result of ineffective regulation, supervision and control, hence there is a need for the enhancement of the relevant parties' administrative performance. Conflict of interest between the regulatory committee and business actors must be eliminated, or at least reduced to the minimum. There is a need to reaffirm BRTI's authorities by reverting them to its regulatory and supervisory functions. The licensing and control function should be the ex-officio authority of the Directorate General for Operations and also Ditjen Aptika. Those Directorate general should coordinate in serial process to make the e-system used in CP services became accountable or trustworthy to the public.

3. The opportunity for misappropriation also arises as a result of the noncomprehensive telecommunications operational eligibility test which does not include examination of the computer program application system used. Therefore, the introduction of every additional feature or new application in the old application system already in operation should also be based on notification and approval from the fostering and supervisory agency concerned.

4. In the context of corporations, dispute resolution should be aimed at civil law settlement, whereby judicial decisions granting immaterial claims could function as "punitive damages" to serve as a lesson to operators, thus 
discouraging them from making such and similar activities become the nature of their business. Operators must recover consumers' rights by paying a certain amount of compensation for damages to them.

5. At the same time, in view of criminal law settlement in the context of corporations, implementing the criminal punishment under the Consumer Protection Law should be sufficiently effective rather than indonesian general criminal code (KUHP). Imposing the criminal punishment of fine, in addition to administrative and civil law penalties, should be more adequate in teaching a bitter lesson to the business actors concerned rather than making the director going to the jail. The objective of the law should be the enhancement of services and the appropriate improvement of the system, rather than the extinction of the corporation itself which also provides services to the public. Applying the general criminal provisions as provided for under the Criminal Code is relevant only in cases which involve individuals or elements in a corporation who abuse their authorities and take benefit from it.

6. In view of recommendations for future improvements in the area of operations, Kominfo needs to take initiative in combining the convergence of the functions and work of various independent institutions supporting state administration and consisting of representatives of business actors and the community (Self Regulatory Organization) which are related to the convergence of telematics. By doing so, it is expected that a more comprehensive policy contents for regulation which effectively accommodates the future dynamics of telematics technology can be achieved appropriately.

\section{Bibliography}

\section{Books}

Buckley, John. Telecommunications Regulation, London: The Institution of Electrical Engineers, 2003

\section{Regulations}

Republic of Indonesia, Law No.8 Year 1999 concerning Consumer protection, Republic of Indonesia, Law No.36 Year 1999 concerning Telecommunications, Republic of Indonesia, Law No.11 Year 2008 concerning Electronic Information and Transactions

Ministerial Regulation No: 1/Per/M.Kominfo/01/2009 Year 2009 concerning Operating Premium Message Services and Short Text Messaging to Multiple Destinations (Broadcast)

\section{Website}

Detik.com. (2012). Police: Losses from Toll Theft More Than Rp 1 Trilion, accessed at http://inet.detik.com/read/2012/03/22/190313/1874860/328/ polisi-kerugian-pencurian-pulsa-lebih-dari-rp-1-triliun. 